ISSN : 2303-1514 | E-ISSN : 2598-5949

\title{
DEVELOPING ANIMAKER-BASED ANIMATION VIDEOS ON THE THEME OF "DAERAH TEMPAT TINGGALKU" AT GRADE IV SDN BANJARSARI 2 SERANG
}

\author{
Anggun Mardhina Ningtyas ${ }^{1}$, Ratna Sari Dewi ${ }^{2}$, M. Taufik ${ }^{3}$ \\ ${ }^{1,2,3}$ Universitas Sultan Ageng Tirtayasa, Indonesia \\ langgunmardhina@gmail.com, ${ }^{2}$ ratna@untirta.ac.id, ${ }^{3}$ taufikmalalak@gmail.com
PENGEMBANGAN VIDEO ANIMASI BERBASIS ANIMAKER PADA TEMA DAERAH TEMPAT TINGGALKU DI KELAS IV SDN BANJARSARI 2 KOTA SERANG

\begin{tabular}{|c|c|}
\hline ARTICLE HISTORY & ABSTRACT \\
\hline $\begin{array}{l}\text { Submitted: } \\
\text { 14 Juni } 2021 \\
14^{\text {th }} \text { June } 2021\end{array}$ & $\begin{array}{l}\text { Abstract: Media is something that cannot be separated from a learning process. Variations in } \\
\text { the use of media are necessary to make students motivated to learn. This research aimed to } \\
\text { produce a product of animaker-based animation video. The type of this research was Research } \\
\text { and Development (R\&D) using the Borg and Gall model which had been modified by Sugiyono. } \\
\text { This model consisted of six stages: potential and problem analysis, data collection, product } \\
\text { design, product design validation, product revision, and product testing. The subjects of this } \\
\text { study were } 39 \text { grade IV students of SDN Banjarsari } 2 \text { Serang. This product was tested to } 20 \\
\text { students in a limited trial. Based on the results of data analysis, it was found that 1) the } \\
\text { percentage of the average score from expert validation was } 84.7 \% \text { which was included in "very } \\
\text { feasible" category; 2) the percentage of the average score from students' responses was } \\
92.72 \% \text { which was included the "very good" category. }\end{array}$ \\
\hline
\end{tabular}

Keywords: animation video, animaker, grade IV elementary school

Accepted:

12 Juli 2021

$12^{\text {th }}$ July 2021

Published:

25 Agustus 2021

$25^{\text {th }}$ August 2021

\begin{abstract}
Abstrak: Media merupakan hal yang tidak dapat dipisahkan dari sebuah proses pembelajaran. Dalam penggunaan media perlu adanya variasi sehingga dapat membuat peserta didik menjadi tidak jenuh. Penelitian dan pengembangan ini bertujuan untuk menghasilkan sebuah produk video animasi berbasis animaker. Penelitian ini merupakan jenis penelitian dan pengembangan atau Research and Development $(R \& D)$ dengan menggunakan model Borg and Gall yang telah dimodifikasi oleh Sugiyono yang terdiri dari enam langkah tahapan pengembangan yaitu analisis potensi dan masalah, pengumpulan data, desain produk, validasi desain produk, revisi produk dan uji coba produk. Subjek penelitian ini adalah peserta didik kelas IV SDN Banjarsari 2 Kota Serang yang berjumlah 39 peserta didik yang diambil 20 peserta didik pada uji coba terbatas. Berdasarkan hasil analisis data diperoleh hasil 1) skor rata-rata dari validasi ahli dengan persentase sebesar $84.7 \%$ yang termasuk dalam kategori "sangat layak"; 2) skor rata-rata dari respon siswa dengan persentase sebesar $92.72 \%$ yang termasuk dalam kategori "sangat baik".
\end{abstract}

Kata Kunci: Video Animasi, Animaker, Kelas IV SD

\section{CITATION}

Ningtyas, A. M., Dewi, R. S., \& Taufik, M. (2021). Developing Animaker-Based Animation Videos on the Theme of "Daerah Tempat Tinggalku" at Grade IV SDN Banjarsari 2 Serang. Primary: Jurnal Pendidikan Guru Sekolah Dasar, 10 (4), 739-748. DOI: http://dx.doi.org/10.33578/jpfkip.v10i4.8355.

\section{PENDAHULUAN}

Pendidikan adalah salah satu komponen terpenting dalam kehidupan manusia. Pendidikan juga dapat menjadi sebuah tolak ukur maju atau tidaknya masyarakat pada suatu bangsa. Karena itulah sudah seharusnya setiap individu dapat memperoleh pendidikan dengan sebaik-baiknya agar dapat bermanfaat 
bagi diri individu itu sendiri, keluarga, masyarakat dan juga negaranya. Pentingnya sebuah pendidikan telah tercantum dalam Undang-Undang Dasar 1945 Pasal 31 ayat 4 yang berbunyi "Setiap warga negara berhak mendapat pendidikan". Adanya pasal tersebut membuktikan bahwa pendidikan harus dimiliki oleh seluruh lapisan masyarakat khususnya di Indonesia.

Era modernisasi dan globalisasi, menjadi tantangan tersendiri dalam dunia pendidikan terlebih bagi pemerintah, guru, orangtua dan peserta didik. Tantangan tersebut semakin dirasakan khususnya oleh guru sebagai tenaga pendidik yang ada di sekolah. Guru harus dapat bertindak sebagai fasilitator dalam kegiatan pembelajaran agar kegiatan belajar menjadi lebih efektif dan bermakna. Untuk itu sudah seharusnya seorang guru mampu membuat suasana belajar mengajar yang menyenangkaan dan menarik bagi peserta didik. Salah satu cara yang dapat dilakukan adalah dengan menggunakan media pembelajaran. Media pembelajaran menurut (Daryanto, 2013: 5) merupakan alat bantu yang dapat digunakan oleh guru untuk menyampaikan materi pembelajaran kepada peserta didik dengan cara yang tidak biasa.

Melalui penggunaan media pembelajaran, seorang guru dapat meningkatkan motivasi belajar serta keaktifan peserta didik, sehingga proses pembelajaran dapat menambah khazanah ilmu pengetahuan serta pengalaman baru bagi peserta didik itu sendiri. Salah satunya adalah dengan memanfaatkan kecanggihan teknologi dan informasi yang berkembang saat ini. Hal tersebut seperti yang telah tercantum dalam Peraturan Menteri Pendidikan dan Kebudayaan Republik Indonesia Nomor 81A Tahun 2013 dalam lampiran IV yang menyatakan bahwa Rencana pelaksanaan pembelajaran Kurikulum 2013 harus menerapkan teknologi, informasi, dan komunikasi secara terintegrasi, sistematis sesuai dengan kondisi yang terjadi.

Berdasarkan hasil analisis kebutuhan media pembelajaran melalui wawancara yang dilakukan dengan salah satu guru di SDN Banjarsari 2 Kota Serang bahwa ketersediaan sarana dan prasarana seperti proyektor kurang dimanfaatkan oleh guru pada saat kegiatan proses pembelajaran berlangsung. Hal ini karena guru lebih memilih melakukan pembelajaran dengan hanya menggunakan buku tematik dan lingkungan sekitar sekolah sebagai sumber belajar bagi peserta didik karena dianggap mudah dan praktis

Sehingga pada saat proses pembelajaran dilaksanakan secara jarak jauh akibat pandemi covid-19 proses pembelajaran cenderung monoton dan membosankan karena guru hanya mengirimkan materi pembelajaran melalui grup whatsaap. Hal tersebut terjadi, karena guru sebelumnya belum pernah membuat media berupa video animasi sebagai sarana penunjang untuk menyampaikan informasi pelajaran kepada peserta didik. Salah satu bentuk media yang dapat digunakan sebagai salah satu variasi pada saat proses pembelajaran berlangsung adalah video animasi. Berdasarkan penelitian terdahulu yang dilakukan oleh Delila K. (2020), Yani W. (2020) terkait dengan pengembangan media pembelajaran berupa video animasi dapat mendorong minat belajar peserta didik.

Peran sebuah media dalam mendorong minat dan ketertarikan peserta didik untuk belajar sangatlah penting. Karena selain pendidik, media dapat memberikan pengalaman-pengalaman baru bagi peserta didik itu sendiri. Hal tersebut sejalan dengan Sanjaya (2015: 208-211) yang mengatakan bahwa manfaat media, yaitu dapat menangkap suatu objek atau peristiwa tertentu, dapat memanipulasi keadaan, peristiwa atau objek tertentu, dapat memberikan motivasi belajar peserta didik dan memiliki nilai praktis. Sedangkan Wati (2016: 12-16) yang mengemukakan bahwa manfaat sebuah media pembelajaran yaitu menarik, tidak membuat peserta didik mudah bosan, peserta didik lebih aktif, meningkatkan proses belajar dan memotivasi peserta didik untuk belajar.

Media pembelajaran sendiri terdiri dari 
beberapa jenis, hal ini seperti yang diungkapkan oleh Atin Fatimah (2019: 13) yang menyatakan bahwa media pembelajaran dibagi menjadi tiga yaitu media audio, visual dan audiovisual. Salah satu media pembelajaran yang dapat digunakan dimanapun dan kapanpun tidak terbatas ruang dan waktu adalah media pembelajaran berbentuk video. Busyaeri (2016: 129) mengemukakan bahwa manfaat dari video adalah dapat mengatasi jarak dan waktu, pesan yang disampaikan lebih mudah diingat dan dapat diputar berulang-ulang sehingga sangat cocok apabila digunakan pada saat proses pembelajaran dilaksanakan secara jarak jauh.

Media video dapat dibuat dengan menggunakan aplikasi berbasis online maupun offline, seperti kinemaster, powtoon, animaker, videoscribe dan lain-lain. Aplikasi-aplikasi tersebut dapat membuat tampilan berupa video animasi yang dapat disesuaikan dengan penggunanya. Video animasi sendiri menurut Munir (2015: 318) adalah gambar yang memuat objek yang seolah-olah hidup yang disebabkan oleh kumpulan gambar yang berubah dan berganti sesuai urutannya. Video animasi, dapat membuat peserta didik tertarik karena tampilannya yang sangat sesuai dengan anak-anak. Untuk membuat video animasi dapat menggunakan aplikasi animaker. Delila (2020: 5) animaker adalah sebuah platform atau software pembuat animasi berbasis online. Dalam aplikasi ini telah tersedia berbagai macam background dan karakter yang dibutuhkan. Keunggulan dari media video adalah memudahkan peserta didik untuk memahami pelajaran karena video dibuat secara audiovisual selain itu media video bertujuan untuk membuat kegiatan belajar yang menyenangkan sehingga peserta didik dapat termotivasi untuk belajar. Berdasakan hal tersebut maka rumusan masalah dalam penelitian dan pengembangan ini adalah bagaimana proses pengembangan, tingkat kelayakan, dan respons peserta didik terhadap video animasi berbasis animaker.

\section{METODE PENELITIAN}

Penelitian ini merupakan jenis penelitian dan pengembangan atau yang disebut dengan research and development (R\&D). Sugiyono (2015:407) Metode penelitian dan pengembangan atau biasa yang disebut dengan R\&D adalah suatu penelitian yang bermaksud menghasilkan produk dan menguji keefektifan produk tersebut. Pada penelitian R\&D ini akan menghasilkan produk berupa media video animasi berbasis animaker. Pengembangan media video animasi berbasis animaker ini menggunakan tahap pengembangan dari Borg and Gall yang telah dimodifikasi oleh Sugiyono menjadi 6 tahap yaitu, 1) Potensi dan masalah, 2) Pengumpulan data, 3) Desain produk, 4) Validasi desain, 5) Revisi media, 6) Uji coba produk secara terbatas. Pelaksanaan uji coba produk pada tanggal 24 April 2021 dilakukan dengan membagi peserta menjadi 2 kelompok, yaitu kelompok pagi dan siang. Langkah-langkah dalam penelitian dan pengembangan (R\&D) ditujukkan pada gambar berikut ini:

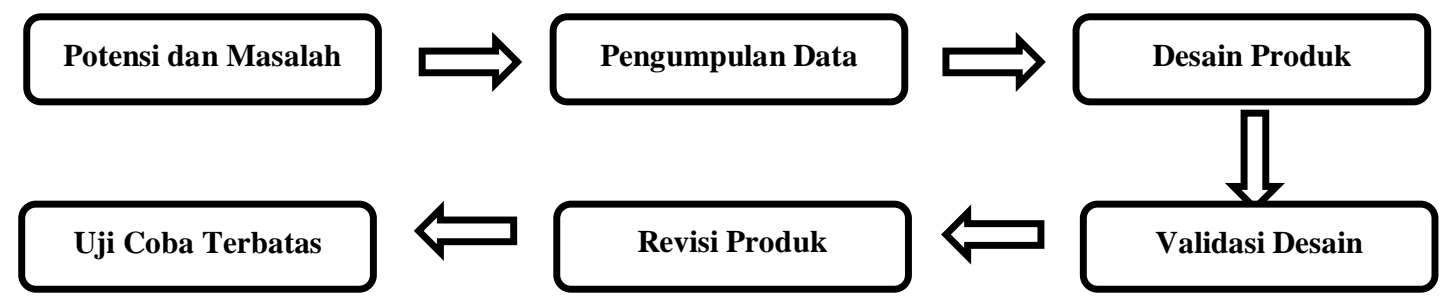

Gambar 1. Langkah-langkah penelitian dan pengembangan (Sugiyono 2015: 409) 


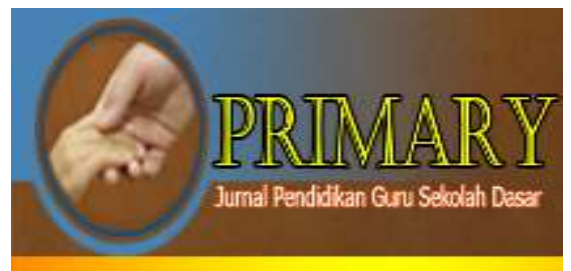

\author{
PRIMARY: JURNAL PENDIDIKAN GURU SEKOLAH DASAR \\ VOLUME 10 NOMOR 4 AGUSTUS 2021 \\ ISSN : 2303-1514 | E-ISSN : 2598-5949 \\ DOI : http://dx.doi.org/10.33578/jpfkip.v10i4.8355 \\ https://primary.ejournal.unri.ac.id/index.php/JPFKIP
}

Tahap pertama dari penelitian ini adalah analisis potensi dan masalah yang terdiri dari analisis kurikulum, analisis kebutuhan dan analisis materi. selanjutnya pada tahap keduaadalah pengumpulan data untuk melakukan perencanaan dalam mengembangkan produk berupa produk yang nantinya dapat membantu guru dan peserta didik dalam proses pembelajaran. Teknik pengumpulan data yang digunakan adalah wawancara, angket dan dokumentasi.

Tahap ketiga yaitu desain produk berdasarkan data yang telah dikumpulkan. Tahap keempat validasi desain untuk mengetahui kelayakan video animasi berbasis animaker yang telah dikembangkan sebelum melakukan tahap uji coba produk secara terbatas. Validasi tersebut dilakukan oleh tim ahli media dan tim ahli materi.

Tahap kelima adalah revisi desain, yang dilakukan berdasarkan saran dari tim ahli sehingga nantinya layak untuk diujicobakan di lapangan. Setelah produk telah selesai melalui tahap perbaikan, maka tahap keenam adalah melakukan uji coba produk secara terbatas dengan memberikan angket respons peserta didik terhadap video animasi berbasis animaker dengan menggunakan sampel peserta didik kelas IVB SDN Banjarsari 2 yang berjumlah 20 peserta didik. Berikut ini adalah analisis data validasi ahli dan respons peserta ddik.

1. Analisis kelayakan Penilaian Validasi Ahli

$\mathrm{NP}=\frac{R}{S M} \times 100 \%($ Purwanto, 2013: 102)

Keterangan:

NP : Nilai Presentase yang diharapkan

$\mathrm{R}$ : Skor mentah yang diperoleh

SM : Skor maksimal ideal 100\%

Kriteria interpretasi skor persentase yang didapatkan dari uji kelayakan penilaian, yaitu sebagai berikut:

Tabel 1. Kriteria Pemberian Skor

\begin{tabular}{cc}
\hline Kriteria & Interpretasi \\
\hline Sangat Layak & 5 \\
Layak & 4 \\
Cukup Layak & 3 \\
Kurang Layak & 2 \\
Sangat tidak Layak & 1 \\
\hline
\end{tabular}

Hasil penilaian yang diperoleh kemudian

(Sugiyono, 2015: 135)

diinterpretasikan sesuai dengan tabel berikut ini:

Tabel 2. Kriteria Interpretasi Validasi Ahli

\begin{tabular}{cc}
\hline Persentase Pencapaian (\%) & Interpretasi \\
\hline $0 \%-20 \%$ & Sangat Tidak Layak \\
$21 \%-40 \%$ & Tidak Layak \\
$41 \%-60 \%$ & Cukup Layak \\
$61 \%-80 \%$ & Layak \\
$81 \%-100 \%$ & Sangat Layak \\
\hline & (Riduwan, 2015: 15)
\end{tabular}


2. Analisis penilaian angket respons Peserta Didik

Tabel 3. Kategori Penilaian Skala Guttman

\begin{tabular}{cc}
\hline Skor & Keterangan \\
\hline Skor 1 & Ya \\
Skor 0 & Tidak \\
\hline & (Sugiyono, 2015:139)
\end{tabular}

Hasil angket tersebut dihitung menggunakan rumus berikut ini:

$$
\mathrm{NP}=\frac{\mathrm{n}}{\mathrm{N}} \times 100 \%
$$

$\mathrm{N}$ : Jumlah skor total untuk setiap indikator $100 \%$

(Riduwan, 2009: 40)

\section{Keterangan:}

NP : Presentase persepsi peserta didik pada tiap indikator

$\mathrm{n}$ : Jumlah skor perolehan peserta didik setiap indikator
Hasil penilaian yang diperoleh kemudian diinterpretasikan sesuai dengan tabel berikut ini:

Tabel 4. Kriteria Interpretasi Respons Peserta Didik

\begin{tabular}{cc}
\hline Persentase Pencapaian (\%) & Interpretasi \\
\hline $0 \%-20 \%$ & Sangat Tidak Layak \\
$21 \%-40 \%$ & Tidak Layak \\
$41 \%-60 \%$ & Cukup Layak \\
$61 \%-80 \%$ & Layak \\
$81 \%-100 \%$ & Sangat Layak \\
\hline & (Riduwan, 2015: 15)
\end{tabular}

\section{HASIL DAN PEMBAHASAN}

Penelitian dan pengembangan ini menghasilkan produk berupa video animasi berbasis animaker pada tema Daerah Tempat Tinggalku sebagai media pembelajaran di Kelas IV sekolah dasar SDN Banjarsari 2 layak digunakan. Hasil dari penelitian ini dapat dilihat dari hasil validasi kelayakan yang diberikan oleh tim validator serta respons peserta didik dari hasil uji coba secara terbatas. Penyajian hasil penelitian yang dikembangkan berdasarkan tahapan penelitian pengembangan dengan model Borg and Gall, yaitu tahap analisis potensi dan masalah, pengumpulan data, desain produk, validasi desain produk, revisi desain dan uji coba secara terbatas.
Karena penenlitian ini bertujuan untuk menghasilkan produk video animasi pada tema daerah tempat tinggalku, subtema 1 pembelajaran ke- 4 dan dalam keadaan pandemi covid-19 sehingga tahap uji coba hanya dapat dilaksanakan secara terbatas. Dari 6 tahapan yang telah dilaksanakan diperoleh hasil penelitian sebagai berikut:

\section{Hasil Validasi Ahli/ Kelayakan Produk}

Tahap validasi produk ini bertujuan untuk mengetahui kelayakan produk yang telah dikembangkan. berdasarkan penilaian dari tim ahli yang meliputi validasi ahli media dan ahli materi. Berikut hasil validasi tim ahli media dan materi. 


\section{PRIMARY: JURNAL PENDIDIKAN GURU SEKOLAH DASAR VOLUME 10 NOMOR 4 AGUSTUS 2021 \\ ISSN : 2303-1514 | E-ISSN : 2598-5949 \\ DOI : http://dx.doi.org/10.33578/jpfkip.v10i4.8355 https://primary.ejournal.unri.ac.id/index.php/JPFKIP}

Tabel 5. Data Penilaian Validasi Ahli Media

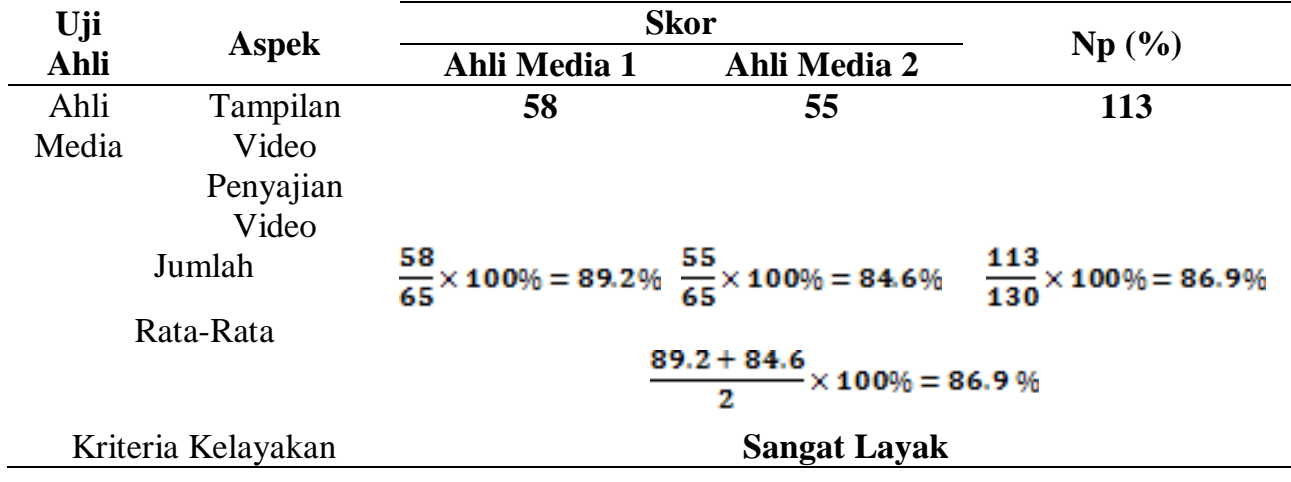

Berdasarkan data penilaian dari tim ahli media tersebut, diperoleh penilaian dari ahli media 1 sebesar $89.2 \%$ dan ahli media 2 sebesar $84.6 \%$ sehingga hasil rata-rata penilaian media sebesar $86.9 \%$ dan masuk kedalam kategori "Sangat Layak" menurut Purwanto (2013: 102).

Tabel 6. Data Penilaian Validasi Ahli Materi

\begin{tabular}{|c|c|c|c|c|}
\hline \multirow{2}{*}{$\begin{array}{l}\text { Uji } \\
\text { Ahli }\end{array}$} & \multirow{2}{*}{ Apek } & \multicolumn{2}{|c|}{ Skor } & \multirow{2}{*}{ Np (\%) } \\
\hline & & Ahli Materi 1 & Ahli Materi 2 & \\
\hline \multirow{6}{*}{$\begin{array}{l}\text { Ahli } \\
\text { Media }\end{array}$} & Isi Materi & 51 & 48 & 99 \\
\hline & Penyajian & & & \\
\hline & Kaidah Bahasa & & & \\
\hline & Jumlah & $\frac{51}{60} \times 100 \%=85 \%$ & $\frac{48}{60} \times 100 \%=80 \%$ & $\frac{99}{120} \times 100 \%=82.5 \%$ \\
\hline & Rata-Rata & \multirow{2}{*}{\multicolumn{3}{|c|}{$\frac{85+80}{2} \times 100 \%=82.5 \%$}} \\
\hline & & & & \\
\hline Krit & ria Kelayakan & \multicolumn{3}{|c|}{ Sangat Layak } \\
\hline
\end{tabular}

Berdasarkan data penilaian dari tim ahli materi tersebut, diperoleh penilaian dari ahli materi 1 sebesar $85 \%$ dan ahli materi 2 sebesar $80 \%$ sehingga hasil rata-rata penilaian materi sebesar $82.5 \%$ dan masuk kedalam kategori "Sangat Layak" menurut Purwanto (2013: 102).

\section{Hasil Angket Respons Peserta Didik}

Angket digunakan untuk mengetahui bagaimana respons peserta didik terhadap produk yang telah peneliti kembangkan. Responden pada penelitian ini sebanyak 20 peserta didik kelas IV di SDN Banjarsari 2. Berikut ini adalah hasil angket respons peserta didik.

Tabel 7. Data Hasil Respons Peserta Didik

\begin{tabular}{llll}
\hline Aspek & Media & Materi & Manfaat \\
\hline Skor & 110 & 38 & 56 \\
Presentase (\%) & 91.6 & 95 & 93.3 \\
Kriteria & Sangat Baik & Sangat Baik & Sangat Baik \\
\hline
\end{tabular}

Berdasarkan data angket respons peserta didik tersebut, diperoleh rata-rata sebesar $92.72 \%$ dan masuk kedalam kategori
"Sangat Baik". Berdasarkan tabel interpretasi menurut Riduwan (2015: 15). Dengan demikian, produk yang dikembangkan yaitu 


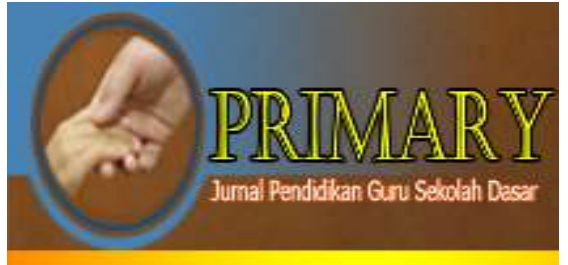

\section{PRIMARY: JURNAL PENDIDIKAN GURU SEKOLAH DASAR VOLUME 10 NOMOR 4 AGUSTUS 2021}

ISSN : 2303-1514 | E-ISSN : 2598-5949

DOI : http://dx.doi.org/10.33578/jpfkip.v10i4.8355

https://primary.ejournal.unri.ac.id/index.php/JPFKIP

video animasi berbasis animaker mendapatkan repons yang sangat positif dari peserta didik.

Produk akhir dari penelitian dan pengembangan ini adalah video animasi berbasis animaker pada tema daerah tempat tinggalku, subtema 1 pembelajaran ke-4. Yang
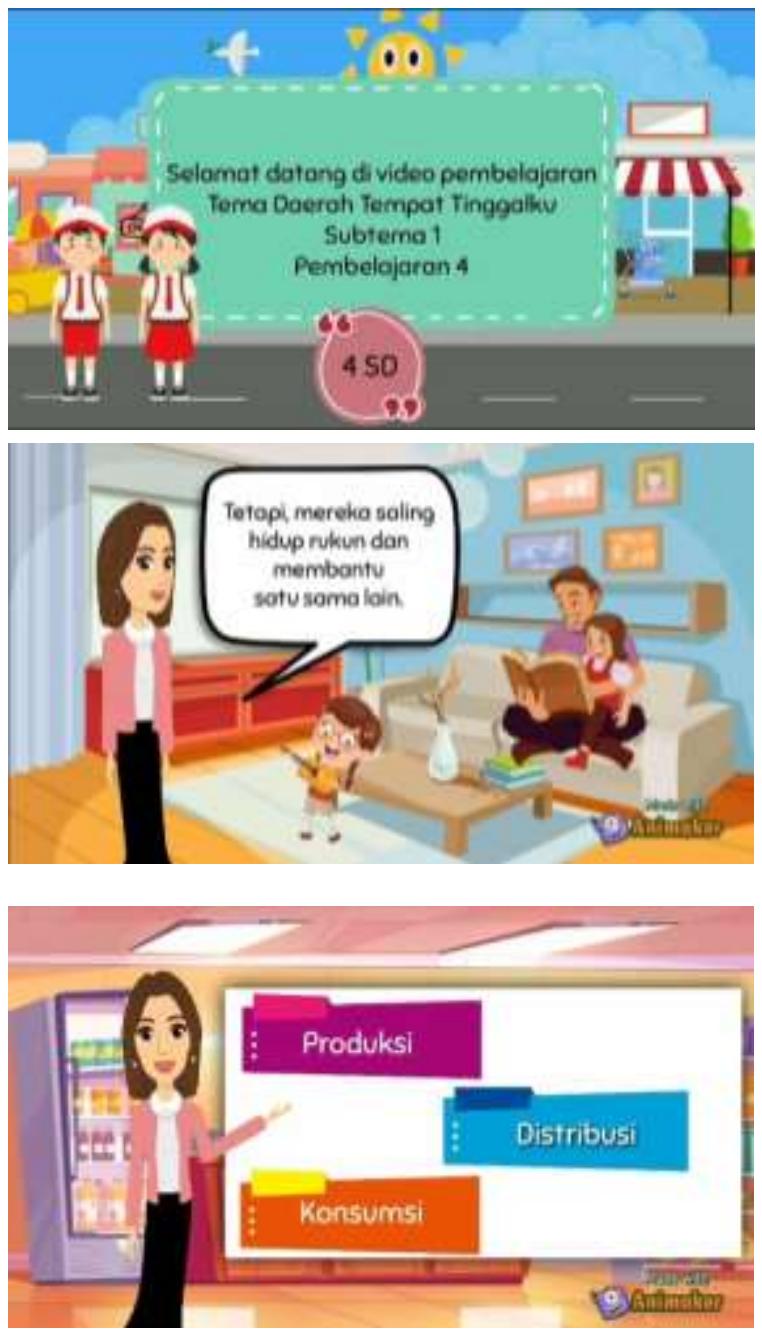

memuat tiga mata pelajaran yaitu, Bahasa Indonesia, PPKn dan IPS yang dikemas dengan animasi menarik sehingga dapat menjadi sesuatu hal yang baru bagi peserta didik.
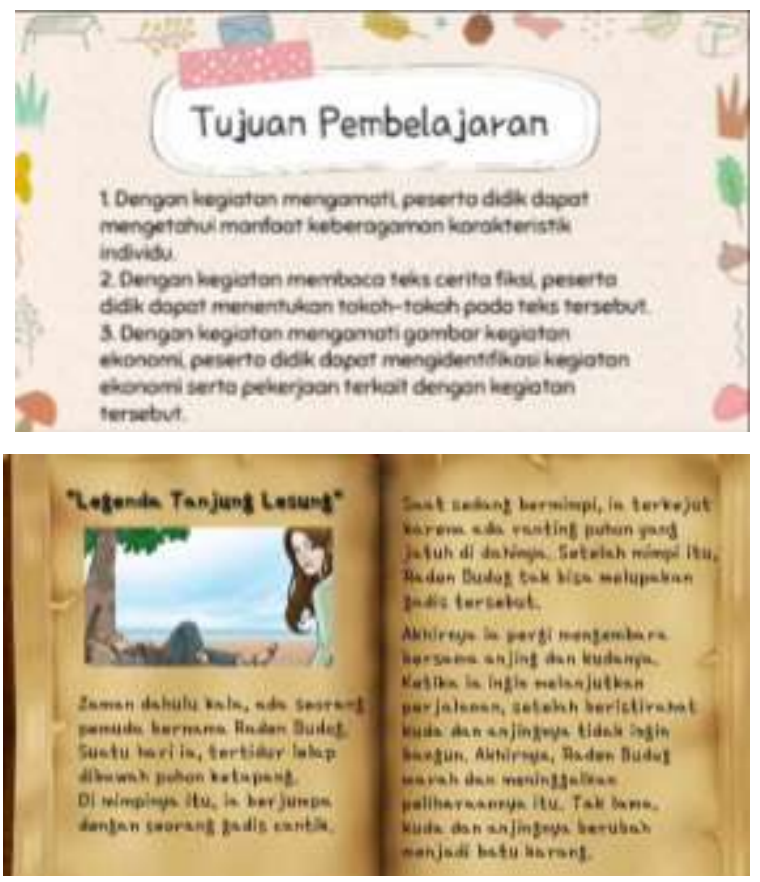

\section{Gambar 2. Produk Akhir Video Animasi Berbasis Animaker}

Ketika pelaksanaan uji coba menggunakan video animasi berbasis animaker, peneliti menemukan temuan penelitian saat proses pelaksanaan pembelajaran. Peserta didik terlihat lebih aktif pada saat belajar, peserta didik dapat lebih meudah memahami materi yang sedang

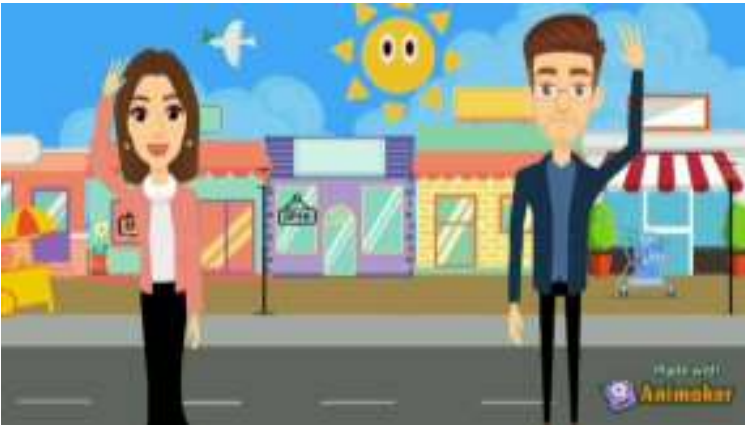

dielajari, saling mengutarakan pendapat berdasarkan pengalamannya, serta tidak terlihat bosan. Hal ini sejalan dengan Wati (2016:62) yang mengemukakan bahwa kelebihan dalam menggunakan video animasi dalam proses pembelajaran adalah video dapat menarik perhatian peserta didik, dapat 
menghemat waktu, dapat diputar secara berulang, guru dapat memberikan kontrol secara penuh. Penelitian yang pernah dilakukan oleh Izomi Awalia (2019) mengatakan bahwa media pembelajaran berbentuk animasi dapat memberikan pemahaman lebih pada saat proses pembelajaran berlangsung. Penelitian yang mpernah dilakukan oleh Delila K (2020) menunjukkan hasil positif dari penggunaan video animasi karena peserta didik terlihat sangat antusias dan mdapat meningkatkan minat belajar peserta didik.

Kekurangan yang peneliti temukan pada saat uji coba produk berlangsung adalah guru harus dapat senantiasa menjaga fokus dari peserta didik, dibutuhkan perlatan yang memadai seperti pc/laptop, proyektor dan juga speaker. Hal ini sesuai dengan apa yang dikemukakan oleh Sanjaya (2015:221) bahwa kekurangan dalam menggunakan media berbentuk video yaitu 1) Jangkauan terbatas, 2) Sifat komunikasi cenderung satu arah, 3) Tampilan gambar relatif. Sedangkan Johari (2014:11) mengatakan bahwa kekurangan media video adalah 1) hanya dapat digunakan dengan peralatan yang mendukung, 2) membutuhkan waktu pada proses pembuatannya, 3) membutuhkan biaya yang cukup besar.

\section{SIMPULAN DAN REKOMENDASI}

Berdasarkan hasil penelitian dan pengembangan yang telah dilakukan, maka dapat diambil kesimpulan sebagai berikut:

1. Produk akhir yang dikembangkan yaitu video animasi berbasis animaker dapat memberikan pengalaman baru, menjadikan peserta didik antusias dalam belajar, dapat menarik perhatian peserta didik dan menjadikan proses pembelajaran menjadi lebih bermakna.

2. Kelayakan video animasi berbasis animaker memperoleh penilaian dengan presentase $86.9 \%$ dari dua ahli media dan $82.5 \%$ dari dua ahli materi. sehingga diperoleh rata-rata sebesar 84.7\% dengan kategori "Sangat Layak".

3. Respons peserta didik terhadap video animasi berbasis animaker dengan uji coba lapangan dengan melibatkan 20 peserta didik memperoleh presentase sebesar 92.72\% termasuk kedalam kategori "Sangat Baik"

Berdasarkan penelitian yang telah dilakukan, maka peneliti mengajukan saransaan sebagai berikut: 1) Bagi Sekolah, video animasi ini dapat dijadikan salah satu media yang dapat digunakan pada proses pembelajaran. Sehingga ketersediaan alat seperti proyektor dan speaker dapat digunakan dan dimanfaatkan sebagaimana mestinya. 2) Bagi Guru, video animasi ini dapat dijadikan alternatif pilihan media ataupun variasi media yang dapat digunakan pada tema 8 , subtema 1 , pembelajaran ke-4 yang memuat 3 muatan pelajaran yaitu PPKn, Bahasa Indonesia dan IPS pada kelas IV Sekolah Dasar disemester II. Sehingga dapat memudahkan pendidik dalam menyampaikan materi pembelajaran dan diharapkan dapat menjadi media yang menarik bagi peserta didik sehingga peserta didik tidak mudah bosan. 2) Bagi Pembaca, kepada para pembaca dan peneliti selanjutnya agar dapat mengembangkan media berupa video animasi berbasis animaker ini pada tema dan materi pelajaran lainnya. 4) Bagi Peneliti, dari penelitian dan pembuatan video animasi berbasis animaker semoga dapat menjadi motivasi lebih baik lagi untuk kedeannya. Sehingga kedepannya dapat membuat media pembelajaran yang lebih baik lagi berikutnya. Serta dapat memberikan manfaat yang bermakna bagi peserta didik.

\section{Daftar Pustaka}

Akbar, S., A'yun, I. Q., Satriyani, F. Y., Widodo, W., Paranimmita, R., dan Ferisa, D. (2016). Implementasi Pembelajaran Tematik di Sekolah Dasar. Bandung: PT Remaja Rosdakarya.

Arifin, Z. (2014). Penelitian Pendidikan. Bandung: PT Remaja Rosdakarya. 
Arikunto, S. (2013). Prosedur Penelitian: Suatu Pendekatan Praktik. Jakarta: PT Rineka Cipta.

Aris, S. (2019). Pembuatan Video Pembelajaran Bagi Guru-Guru SMPN 1 Karimunjawa. Seminar Nasional Kolaborasi Pengabdian Kepada Masyrakat UNDIP-UNNES. 289-293.

Arsyad, A. (2011). Media Pembelajaran. Jakarta: Raja Grafindo Persada.

Awalia, I., Aan, S. P., dan Trian, P. A. (2019). Pengembangan Media Pembelajaran Animasi Powtoon Pada Mata Pelajaran Matematika di Kelas IV SD. Kreano: Jurnal Matematika Kreatif-Inovatif. 10(1): 49-56.

Ayuningdyah, M., dan Khusnul, K. (2018). Pengembangan Media Animasi Pelajaran Matematika Materi Bangun Datar Simetris Untuk Siswa Kelas IV di SDN Jatikalen 3 Nganjuk. Jurnal Teknologi Pendidikan. 0(1): 1-5.

Binanto, I. (2010). Multimedia Digital-Dasar Teori dan Pengembangannya. Yogyakarta: Andi.

Busyaeri, A., Tamsik, U., dan A. Zaenuddin. (2016). Pengaruh Penggunaan Video Pembelajaran Terhadap Peningkatan Hasil Belajar Mapel IPA di MIN Kroya Cirebon. Al Ibtida. 3(1): 116-137.

Daryanto. (2013). Media Pembelajaran. Yogyakarta: Gava Media.

Depdiknas. (2006). Permendiknas No. 22 Tahun 2006 Tentang Standar Isi. Jakarta: Depdiknas.

Depdiknas. (2006). Model Pembelajaran Tematik. Jakarta: Puskur Balitbang Depdiknas.

Fatimah, A. (2019). Media dan Sumber Belajar. Serang: PGPAUD FKIP UNTIRTA.

Hasyim, A. (2016). Metode Penelitian dan Pengembangan di Sekolah. Yogyakarta: Media Akademi.

Johari, A., Syamsuri, H., dan Maman, R. (2014). Penerapan Media Video dan Animasi Pada Materi Memvakum dan
Mengisi Refrigeran Terhadap Hasil Belajar Peserta Didik. Jurnal of Mechanical Engineering Education. 1(1): 8-15.

Majid, A. (2013). Strategi Pembelajaran. Bandung: PT Remaja Rosdakarya.

Mashuri, D. K. (2020). Pengembangan Media Pembelajaran Video Animasi Materi Volume Bangun Ruang Untuk SD Kelas $V$. JPGSD. 8(5): 893-903.

Munadi, Y. (2010). Media Pembelajaran: Sebuah Pendekatan Baru. Jakarta: GP Press Group.

Munir. (2015). Multimedia Konsep dan Aplikasi Dalam Pendidikan. Bandung: Alfabeta.

Naserly, M. K. (2018). Pemanfaatan Video Sebagai Media Latihan Dalam Pembelajaran Bahasa Inggris. Akrab Juara. 3(4): 107-116.

Peraturan Menteri Pendidikan dan Kebudayaan RI No. 81 A Tahun 2013.

Purwanto. (2013). Evaluasi Hasil Belajar. Yogyakarta: Pustaka Belajar.

Riduwan. (2009). Skala Pengukuran VariabelVariabel Penelitian. Bandung: Alfabeta.

Riduwan. (2015). Dasar-Dasar Statistika. Bandung: Alfabeta.

Riyana, C. (2007). Pedoman Pengembangan Media Video. Jakarta: P3AI UPI.

Rusman. (2011). Model-Model Pembelajaran: Mengembangkan Profesionalisme Guru. Jakarta: Rajawali Pers.

Samsudin. (2008). Pembelajaran Pendidikan Jasmani Olahraga Dan Kesehatan SD/MI. Jakarta: Litera Prenada Media Group.

Sanaky, H. A. H. (2013). Media Pembelajaran Interaktif-Inovatif. Yogyakarta: Kaubaka Dipantara.

Sanjaya, W. (2015). Perencanaan dan Desain Sistem Pembelajaran. Jakarta: Prenadamedia Group.

Sudjana., dan Ahmad, R. (2013). Media Pengajaran. Bandung: Sinar Baru Algensindo. 


\section{PRIMARY: JURNAL PENDIDIKAN GURU SEKOLAH DASAR \\ VOLUME 10 NOMOR 4 AGUSTUS 2021 \\ ISSN : 2303-1514 | E-ISSN : 2598-5949 \\ DOI : http://dx.doi.org/10.33578/jpfkip.v10i4.8355 \\ https://primary.ejournal.unri.ac.id/index.php/JPFKIP}

Sugiyono. (2014). Metode Penelitian Kuantitatif, Kualitatif, dan RnD. Bandung: Alfabeta.

Sugiyono. (2015). Metode Penelitian Pendidikan Pendekatan Kuantitaif,Kualitatif dan RnD. Bandung: Alfabeta.

Sukmadinata, N. S. (2017). Metode Penelitian Pendidikan. Bandung: PT Remaja Rosdakarya.

Suryani, N., Achmad, S., dan Aditin, P. (2018). Media Pembelajaran Inovatif dan Pengembangannya. Bandung: PT Rosdakarya.

Undang-Undang Dasar 1945 Pasal 31 Ayat 4

Wati, E. R. (2016). Ragam Media Pembelajaran. Jakarta: CV Solusi Distribusi.
Widyastuti., dan Nurhidayati. (2010). Pengembangan Media Pembelajaran Bahasa Jawa. Diklat Mata Kuliah Media Pembelajaran. Yogyakarta: Universitas Yogyakarta.

Wirasasmita, R. H., dan Putra, Y. K. (2015). Pengembangan Media Pembelajaran Video Tutorial Interaktif Menggunakan Aplikasi Camtasia Studio dan Macromedia Flash. Education. 1(2): 262279.

Wulandari, Y., Yayat, R., dan Lukman, N. (2020). Pengembangan Media Video Berbasis Powtoon Pada Mata Pembelajaran IPA Di Kelas $V$. EDUMATIC: Jurnal Pendidikan Informatika. 8(2): 35-43. 